\title{
Comparison of detergent and CTAB method for isolation of DNA from Salak (Salacca zalacca (Gaert.) Voss. 'Pondoh')
}

\author{
Namira Nur Arfa ${ }^{1, *}$, Budi Setiadi Daryono ${ }^{2}$, Reflinur ${ }^{3}$ \\ ${ }^{1,2}$ Faculty of Biology, Universitas Gadjah Mada, Jl. Bulaksumur, Yogyakarta, 55281, Indonesia Tel. +62-274-6492599, Fax. +62-274-565223 \\ ${ }^{3}$ Laboratory of Molecular Biology, Balai Besar Bioteknologi dan Sumber Daya Genetik Pertanian (BB-Biogen), Bogor, Indonesia \\ Author correspondency*: \\ namiranurarfa@ rocketmail.com
}

\begin{abstract}
This study conducted in Laboratory of Molecular Biology, Balai Besar Bioteknologi dan Sumberdaya Genetik Pertanian (BB- Biogen) Bogor. The aims of this study were to determine and comparing the quantity, quality and the efficiency of DNA isolation result using detergent method and CTAB method. The parameters observed in this study were the value of DNA concentration, purity, and visualization result using gel electrophoresis. The samples were the leaves of Salak 'Pondoh' (Salacca zalacca (Gaert.) Voss.). Detergent method is a method which was developed by Faculty of Biology UGM, it has simple procedure and relatively affordable cost. Meanwhile, CTAB method is one of the commonly used methods of DNA isolation protocol with relatively expensive cost. Detergent method used detergent in the cell wall separation and protein removal in the sample. The CTAB method used Cetyltrimethyl ammonium bromide (CTAB) for cell membrane separation in the sample. The research methods included DNA isolation with detergent and CTAB methods, PCR analysis and electrophoresis. Data analysis was done quantitatively using spectrophotometric method and qualitative used electrophoresis method. The result of the study showed that DNA isolation using CTAB method showed higher purity compared with detergent method with the purity values ranging from 1,3-1,4. Meanwhile, the concentration of DNA in the detergent method was higher than that of CTAB with the highest concentration of $1730 \mu \mathrm{g} / \mathrm{ml}$. There is no difference between the quality of genomic DNA isolated by CTAB and detergent methods.
\end{abstract}

Keywords: CTAB; detergent; DNA isolation; Salak (Salacca zalacca (Gaert.) Voss.)

\section{INTRODUCTION}

Indonesia is a megabiodiversity country which has enormous exotic tropical fruits, such as Pinneapple, mangosteen and salak (Suhandy et al., 2010). Salak or known as snake fruit, salak palm and snake palm (Lim 2012) belong to genus Salacca Reinwardt. So far 21 species of Salacca have been identified (Supapvanich et al., 2011) and dispersed naturally in Malesia area, such as Birma, Thailand, Malaysia, Philliphines, Cambodia, Sumatera, Java and Borneo (Mogea 1980). Salacca growth on primary tropical rain forest with optimal temperatures $22^{\circ} \mathrm{C}-32^{\circ} \mathrm{C}$ and high humidity (Ni Made 2005). Salak has sweet taste, crunchy texture and high nutritional and economical value. Salak plant classified into Palmae family and can be planted in many regions in Indonesia, either by cultivation or growing as a wild plants (Haryanto 2010). Salak fruit can be made as cuisine, such as salad, pickles, jam or crackers (Lim 2012).

Three kinds of Salak which already cultivated are Salacca sumaterana Becc. in Sidempuan, (Salacca zalacca (Gaert.) Voss.) in Bali, Ambon and also Salacca wallichiana in Thailand. Salacca zalacca var zalacca divided into some local cultivar, such as Salak Bongkok in Sumedang, Salak Petruk in Ambarawa, Salak Pondoh, Salak Gading and Salak Kembang Arum in Sleman,
Salak Condet in Condet and Salak Nglumut in Magelang (Harsono \& Hartana 2003). Salak 'Pondoh' is a new cultivar originated from Yogyakarta (Supriyadi et al., 2002). The varieties of Salak Pondoh that had been cultivated in Indonesia are Salak Pondoh Hitam, Salak Pondoh Merah, Salak Pondoh Kuning and Salak Pondoh Super (Purnomo, 2001).

Indonesia exported high quality salak fruit to some countries such as Singapore, Middle East country, Netherlands, Hongkong and China (Lim, 2012: 433). Salak plants need rain fall about $200-400 \mathrm{~mm} /$ month and usually growth undershades with sun intensity range from 50\%-70\%. Salak growth optimal in $\mathrm{pH} 6,5$ and temperature between $20^{\circ} \mathrm{C}-30^{\circ} \mathrm{C}$ (Suskendriyati et al., 2000). Salak 'Pondoh' (Salacca zalacca (Gaert.) Voss.) is a dioecious plants which are spiny, clustered and grows as a dense clump. The fruit is ovoid shaped, has brown skin which is look like a snake skin (Supriyadi et al., 2002). The leaves are pinnate or palmate with range from 4-7m long (Ni Made, 2012:8) the stem are partly erect and short.

Biodiversity of salak plants are high in each cultivar. Variation in skin type, fruit color, taste and size showed that the plants has high genetic variability. Genetic condition is an important factor in plant breeding, such as crossing over and to extend genetic variability (Annisaurrohmah et al., 2014). Genetic condition of a 
plant is inherited by DNA. In Salak plant, DNA isolation is needed to obtain the pure DNA for genetic analysis in Salak plant breeding. DNA isolation technique is needed to obtain DNA from organism with high purity and concentration. DNA isolation can conduct using SDS method (Sambrook et al. 1982:29), CTAB (Mulyani et al., 2011:2), phenol chloroform method (Tenriulo et al. 2001:2) and detergent method (Nasiri et al., 2005).

DNA isolation technique consists of three main procedures, they are cell lysis, removing the contaminant and purification of DNA (Milligan, 1992: 66). DNA isolation method was chose based on some consideration, such as amount and the molecular weight, purity, time, species and the cost. General method of DNA isolation is CTAB methods, a DNA isolation method which can produce high concentration and purity of DNA, but the cost is expensive. Faculty of Biology Universitas Gadjah Mada develop a DNA isolation technique using detergent method, which is relative easy and cheap. The aim of this study was to compare the result of DNA isolation of salak 'Pondoh' using detergent method and CTAB method. The method can be used to get DNA isolation which is effective, easy, cheap and simple.

\section{MATERIALS AND METHODS}

\section{Procedures \\ Materials}

The material used in this research were the leaves of Salak 'Pondoh' plant from Turi, Sleman, Yogyakarta, aquades, PVP (Polyvinylpyrrolidone), mercaptoethanol, CTAB (Cetyl trimethyl ammonium bromide), taq DNA polymerase, taq DNA buffer, dNTPS mix, nuclease free water, detergent, $\mathrm{dd}_{2} \mathrm{O}$, chloroform: isoamyl alcohol (chisam), agarose, ethidium bromide, TBE (Tris Boric acid EDTA) buffer 0,5 x, primer OPA 13, loading dye, DNA ladder, DNA marker, mineral oil, NaoAC, TE + RNAse

Tools that used in this study were scissor, mortar, glassware, volumetric pipette, pipette tips, PCR thermocycler, vortex, waterbath, sentrifuge, freezer, refrigerator, autoclave, magnetic stirrer, electrophoresis machine, microwave, microtube, microplate, chemidoc software and spectrophotometer.

\section{Methods}

The source of DNA were leaves of Salak 'Pondoh' from Sleman, Yogyakarta. The result of DNA isolation between CTAB methods and detergent method were compared by seeing the optical density and the visualization of DNA band after electrophoresis.

\section{Detergent method}

0,5 gram samples of salak 'Pondoh' leaves were extracted using mortar and stored in microtubes. After that, $1 \mathrm{ml}$ detergent buffer $(1,4 \mathrm{M} \mathrm{NaCl}$, detergent, 100 $\mu \mathrm{TT}$ ris $\mathrm{HCl} \mathrm{pH} 8,20 \mathrm{mM}$ EDTA) are added to the leaves extract. After that, the sample were separated by sentrifuge about 10 minutes at $12.000 \mathrm{rpm}$. After that the supernatant were taken from the juice and filtered using filter paper and added with isopropanol from the wall of the tubes. Then the mixture are shook slowly then the DNA will appear as a white fiber which is DNA band. The isopropanol removed from the bottle, then the DNA were added by $\mathrm{ddH}_{2} \mathrm{O}$ and stored in refrigerator.

\section{CTAB method}

Pre- heat CTAB isolation buffer, after that 0.5 grams of salak 'Pondoh' leaves were extracted using mortar and added by $500 \mu$ l buffer CTAB (Tris $\mathrm{HCl} \mathrm{pH} 8,0 ; 1,4 \mathrm{M}$ $\mathrm{NaCl} ; \quad 20 \mathrm{mM}$ EDTA; $0,2 \%$ CTAB; $0,2 \%$ mercaptoethanol). After that, the sample are homogenized using vortex and incubated in waterbath for 30 minutes at $65^{0}$ Celcius. Every 10 minutes, the tube are turned upside down. After 30 minutes, the mixture are taken from waterbath and added by $500 \mu 1$ chisam (Chloroform: isoamyl alcohol) with ratio 24:1, mixed gently and the samples are turned upside and down for 200 times until the samples are homogeneous. Then, the samples are centrifuged for 10 minutes in $12.000 \mathrm{rpm}$. Supernatant that formed, moved into the another microtubes. Supernatant added by NaoAc $50 \mu 1$ and added cold isopropanol $500 \mu$ to precipitate the DNA. Then the samples were centrifuged in $12000 \mathrm{rpm}$ for 10 minutes to precipitate the DNA. Remove the liquid and wash the DNA using 70\% ethanol and centrifuges by 5 minutes. Remove the liquid and dry the DNA for a night. Add the DNA with $100 \mu \mathrm{l}$ TE RNAse and incubated in $37^{\circ} \mathrm{C}$ about $30-60$ minutes.

\section{PCR analysis}

Amplification of DNA was performed by PCR type My Cycler machine from BioRad, using primer OPA 13 and total PCR reaction of $20 \mu \mathrm{l}$. RAPD condition setting was initial denaturation at $94^{\circ} \mathrm{C}$ for 4 min followed by 44 cycles from $94^{\circ} \mathrm{C}$ for 1 minute, $37^{\circ} \mathrm{C}$ for 1 minutes, and $72^{\circ} \mathrm{C}$ for 2 minutes. After that the temperature was maintained at $72^{\circ} \mathrm{C}$ for 10 minutes, then the temperature was lowered to $4^{\circ} \mathrm{C}$.

Table 1. PCR Composition Table.

\begin{tabular}{lll}
\hline 1 & $\mathrm{ddH}_{2} \mathrm{O}$ & $13,55 \mu \mathrm{l}$ \\
2 & $10 \mathrm{x}$ buffer & $2 \mu \mathrm{l}$ \\
3 & $10 \mathrm{mM}$ dnTPS & $0,2 \mu \mathrm{l}$ \\
4 & Taq Polymerase & $0,25 \mu \mathrm{l}$ \\
5 & DNA & $2 \mu \mathrm{l}$ \\
6 & $5 \mathrm{uM}$ Primer & $2 \mu \mathrm{l}$ \\
\hline & Total volume & $20 \mu \mathrm{l}$ \\
\hline
\end{tabular}




The settings of PCR Program
\begin{tabular}{|c|c|c|}
\hline Cycle & Temperature & Time \\
\hline Pra denaturation & $94^{\circ} \mathrm{C}$ & $00: 04: 00$ \\
\hline Denaturation & $94^{\circ} \mathrm{C}$ & $00: 01: 00$ \\
Annealing & $37^{\circ} \mathrm{C}$ & $00: 01: 00$ \\
Extention & $72^{\circ} \mathrm{C}$ & $00: 02: 00$ \\
\hline Final Extention & $72^{\circ} \mathrm{C}$ & $00: 10: 00$ \\
\hline
\end{tabular}

Figure 1. The settings of PCR program.

\section{Electrophoresis}

\section{- 1 Making Buffer Solution 10xTris Borat EDTA} (TBE)

108 grams tris, 55,2 grams boric acid were added into a $1000 \mathrm{ml}$ beaker glass and added by aquades up to 700 $\mathrm{ml}$. The solution was stirred with a magnetic stirrer until homogen. Next, 9,2 grams of EDTA was added and stirred back with a magnetic stirrer and fed into a $500 \mathrm{ml}$ measuring flask and added to a volume of $500 \mathrm{ml}$. The solution is shaken out to homogeneous. The available buffer solution was 10x concentrated buffer solution, to obtain $0,5 \mathrm{x}$ buffer solution, $10 \mathrm{x}$ buffer solution is taken $50 \mathrm{ml}$ and fed into $1000 \mathrm{ml}$ of measuring flask. Then plus aquades up to $1000 \mathrm{ml}$ and the solution shaken until homogen.

\section{- Preparation of Agarose Gel 2\%}

2 grams of agarose was weighed in $100 \mathrm{ml}$ of $0,5 \mathrm{x}$ TBE solution and allowed to stand at room temperature for 1 minute. The solution was heated by microwave about 2 minutes to a perfect solute solution. The solution is allowed to stand at room temperature to keep it from overheating. The agarose solution is poured onto a mold with a combed comb to make a well on the gel. $0,5 \mathrm{x}$ TBE solution was added to the surface of the solid gel and then the comb was lifted slowly. Place agarose then placed on electrophoresis tank in submerged condition of $0,5 x$ TBE solution.

\section{- Electrophoresis DNA}

The DNA samples and DNA markers were prepared. A $5 \mu \mathrm{l}$ DNA marker was inserted into the left most edge well. The diluted DNA in TE buffer $5 \mu$ then mixed with $3 \mu \mathrm{l}$ of loading dye, then inserted into the $2^{\text {nd }}$ well to the next. After all samples were put into a well, the electrophoresis apparatus was closed and connected to a power source. The power supply was set to $100 \mathrm{v}$ for a 60 minutes and turned on by pressing the $\mathrm{ON}$ button. Once it was done, the tool was turned off. Gel was removed along with its mold from electrophoresis fittings. The gel was stained with ethidium bromide for
2- 5 minutes then rinsed with aquades. Gel was observed with UV transilluminator. The DNA bands will glow and observed with chemidoc software.

\section{Data analysis}

Data analysis conducted by quantitative dan descriptive qualitative of DNA profile using detergent and CTAB method. The factor compared are as follows:

\section{Quantitative factor}

Quantitative factor which measured were optical density from both DNA profile, including DNA total, RNA total, protein, purity and concentration.

\section{Qualitative factor}

Qualitative factor that compared were the result of electrophoresis of DNA profile using detergent and CTAB method after PCR.

\section{RESULTS AND DISCUSSION}

Table 1. Optical density of DNA isolation product from Salak (Salacca zalacca (Gaert.) Voss.) was done using detergent method.

\begin{tabular}{lllll}
\hline No & $\begin{array}{l}\text { Concentration } \\
(\boldsymbol{\mu g} / \mathbf{m l})\end{array}$ & Purity & $\mathbf{\lambda 2 6 0}$ & $\mathbf{\lambda 2 8 0}$ \\
\hline 1. & 725,0433 & 1,1798 & 0,073 & 0,061 \\
2. & 767,4141 & 1,1666 & 0,077 & 0,0 \\
3. & 486,2714 & 1,1989 & 0,049 & 0,041 \\
4. & 1025,8585 & 1,1842 & 0,103 & 0,087 \\
5. & 1076,1797 & 1,1406 & 0,108 & 0,094 \\
6. & 1102,3815 & 1,1891 & 0,110 & 0,093 \\
7. & 1730,4355 & 1,1255 & 0,173 & 0,154 \\
8. & 854,9668 & 1,0139 & 0,085 & 0.080 \\
\hline
\end{tabular}

Table 1 showed optical density of DNA isolation product from salak leaves using detergent method, the purity of DNA isolation product range from 1,01391,1989 with DNA concentration has value 486,2713$1730,4355(\mu \mathrm{g} / \mathrm{ml})$. 
Table 2. Optical density of DNA isolation product from Salak (Salacca zalacca (Gaert.) Voss.) by CTAB method.

\begin{tabular}{lllll}
\hline No & $\begin{array}{l}\text { Concentration } \\
(\boldsymbol{\mu g} / \mathbf{m l})\end{array}$ & Purity & $\mathbf{\lambda 2 6 0}$ & $\mathbf{\lambda 2 8 0}$ \\
\hline 1. & 850,3145 & 1,333 & 0,085 & 0,064 \\
2. & 937,99 & 1,4926 & 0,094 & 0,063 \\
3. & 1112,24 & 1,4388 & 0,111 & 0,077 \\
4. & 909,6155 & 1,441 & 0,091 & 0,063 \\
5. & 858,0715 & 1,5533 & 0,086 & 0,055 \\
6. & 690,5455 & 1,4703 & 0,069 & 0,047 \\
7. & 687,5588 & 1,4232 & 0,069 & 0,048 \\
8. & 491,976 & 1,4700 & 0,049 & 0,033 \\
\hline
\end{tabular}

Table 2 showed optical density of DNA isolation product from salak leaves using CTAB method, the purity of DNA isolation product range from 1,333-1,553 with DNA concentration value 491,976- 1112,24 ( $\mu \mathrm{g} /$ $\mathrm{ml})$.

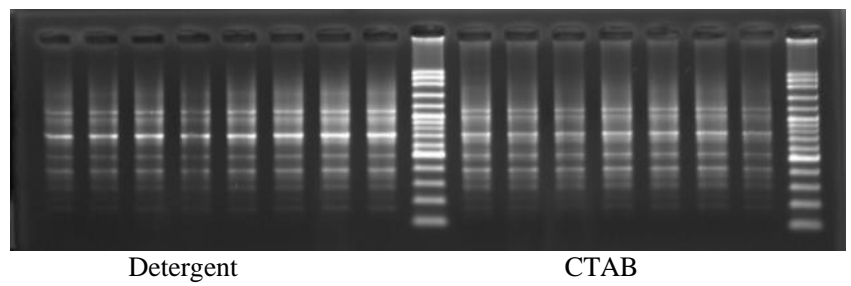

Figure 1. Result of DNA isolation product after PCR using primer OPA 13 (5'-CAgCACCCAC-3').

\section{Discussion}

DNA isolation is the first stage in genetic engineering (Faatih, 2009). DNA isolation defines as a procces to extract DNA from cell organism, and get a pure DNA from another organelles and materials in cells, such as polysaccharides, lipid, RNA and protein. The process of DNA isolation consists of several stages: cell separation, separation of DNA from other components and purification of DNA (Yusdiana, 2008). The process of DNA separation is done by mechanical or physical means using mortar, this is done to extract DNA, cell wall, cell membrane and nuclear membrane so that expected DNA can come out of cell. The next process is the separation of DNA from various organelles and other cell components such as proteins, cellulose, lipids, RNA. The last process is a DNA purification process that aims to purify the DNA so that the results of DNA isolation easily observable and can be judged both in quantity and quality. Optimization of DNA isolation method can be conducted by arranging the lysis buffer composition and method in extract DNA from another compounds in cells (Milligan, 1992).

DNA isolation methods are of several types, such as simple methods using detergents, Nucleon TM Phytopure тм Genomic DNA Extraction Kit method and CTAB (Cetyl trimethyl ammonium bromide) method. $\mathrm{CTAB} / \mathrm{NaCl}$ dan SDS method are conventional and popular DNA isolation method (Fitriya et al., 2011) in extraction of plant which contains high polyphenol and polysaccharides (Ardiana, 2009). In this study we used two methods of DNA isolation and compared the results. Detergent method is using detergent in the process of cell separation, while the CTAB method used CTAB buffer for cell separation process.

The buffer solution in the detergent method consists of EDTA, detergent and $\mathrm{NaCl}$. Salt solution is involved in regulating osmotic pressure in cells. The salt content of the buffer will cause hypertonic conditions outside the cell so that the cells will experience plasmolysis. Detergent will damage the cell wall of the organism. After that the sample was centrifuged by using a centrifuge with a speed of $12000 \mathrm{rpm}$. This centrifugation serves to separate the cell debris or the larger part of the pellet and the smaller, DNA-containing supernatant (Langga et al., 2012). The difference methods of DNA isolation can produce different DNA isolation product. Furthermore, the supernatant was taken using a micropipette and inserted into a new microtube. After that, the supernatant were filtered using filter paper and moved into new microtubes.

Then isopropanol were added from the microtubes wall, this addition was done to prevent isopropanol from evaporating and to avoid spontaneous reactions between the DNA with isopropanol. After that the tubes were turned back slowly to form DNA threads. After the DNA threads were visible, the tube was centrifuged at a rate of $12000 \mathrm{rpm}$ for 5 minutes. The isopropanol were removed then the DNA pellet was dried and dissolved in a TEbuffer solution that acts as a DNA solvent and stored in the freezer.

In the use of isolation method with CTAB buffer, the process of separation was done by CTAB (Cetyl trimethyl ammonium bromide). First, CTAB buffers were made with a composition of $2 \%$ CTAB, $0.5 \mathrm{M}$ EDTA of $20 \mu \mathrm{m}, 1 \mathrm{M}$ Tris $\mathrm{HCl} 1 \mu \mathrm{l}, 2 \% \mathrm{PVP}, 0,2 \%$ mercaptoethanol and $5 \mathrm{M} \mathrm{NaCl}$ of $1.4 \mu \mathrm{l}$. First CTAB buffer was preheated into waterbath at $65^{\circ} \mathrm{C}$. The sample was extracted using mortar until soft. The samples were moved into a $1.5 \mathrm{ml}$ micro-tube and added $500 \mu \mathrm{l}$ of the heated extraction buffer and then mixed well. Incubate the at $65^{\circ} \mathrm{C}$ for 30 minutes and every 10 minutes the tube was reversed for the process.

After $30 \mathrm{~min}$, the mixture was taken from the waterbath and allowed to stand at room temperature for 2 minutes and added with $500 \mu \mathrm{l}$ of chloroform and isoamic alcohol mixture at a ratio of 24: 1 . After that the material spinned down for 5 minutes, it aims to mixed the samples with chloroform. After that, centrifuged for 15 minutes at a speed of $12000 \mathrm{rpm}$. The supernatant formed was then removed and transferred into a new micro tube. The function of incubation in $65^{\circ} \mathrm{C}$ and presipitation using chloroform: isoamyl alcohol was to remove proteins in the cells (Semagn et al., 2006). The functions of adding Polyvinylpyrrolidone (PVP) in the 
early stage of DNA isolation in the CTAB method was to bind the phenolic compounds and to minimize the oxzidation of phenolic compounds (Utami et al., 2012). PVP also can produce thick and clear DNA bands.

The supernatant was then added $1 / 10 \mathrm{CH} 3 \mathrm{COONa}$ and then added with 2 / $3 \mathrm{X}$ isopropanol volume for DNA precipitation. The sample was then centrifuged at a rate of $12000 \mathrm{rpm}$ for 10 minutes to precipitate DNA. The liquid was then removed and the precipitate washed with $70 \%$ ethanol for 10 minutes to precipitate the DNA and centrifuged again for 5 minutes. The liquid was removed and dried. After that the DNA was dissolved with $50 \mu \mathrm{l}$ of TE buffer. After the isolation process was complete, a total quantitative DNA analysis was performed using spectrophotometry and qualitative analysis using electrophoresis.

Table 1 showed that the purity of DNA isolated results with CTAB method is better than detergent method. The detergent method has purity value 1,3-1,5 meanwhile detergent method has value 1,0-1,19. A pure DNA has ratio OD $\lambda$ 260/ 2280 between 1,8-2,0 (Sambrook et al., 1989). Optical Density with value <1 showed that the DNA isolation product was contaminated by compounds such as polysaccharides, protein or phenolic compounds. Meanwhile, Optical Density with value $>2$ showed high RNA accumulation in DNA isolation product. The result showed that the samples are still contaminated with compounds such as proteins or polysaccharides.

DNA concentration in the detergent method has a higher concentration than the DNA concentration by the CTAB method. In the detergent method, the highest concentration value is $1730,4355(\mu \mathrm{g} / \mathrm{ml})$ while the CTAB method has highest value 1112, $24(\mu \mathrm{g} / \mathrm{ml})$. Based on the isolated DNA concentration, it is known that DNA isolation using detergent method is better than using CTAB method. The total DNA was qualitatively done using electrophoresis technique. Stages of electrophoresis technique is done by gel preparation of $2 \%$ agarose. In the running stage electrophoresis was done by using $2 \mu \mathrm{l}$ samples, loading dye $2 \mu \mathrm{l}$ and $\mathrm{H}_{2} \mathrm{O}$ as much as $1 \mu \mathrm{l}$. Loading dye plays a weight and as a marker of DNA to enter into the wells. Running electrophoresis was performed with a 100 volt voltage for 30 minutes.

After running finished, electrophoresis results are inserted into EtBr (Ethidium bromide) to color the DNA. Ethidium Bromide is capable of inserting between the nitrogen bases in the DNA helix. Once stained, electrophoresis results are seen under ultraviolet light by using a UV transluminator. PCR RAPD are conducted to make sure the quality of DNA. PCR is a process of multiplying nucleotide sequences by enzymatic methods at a certain temperature. There are several major components in PCR, including DNA fragments, primers, deoxyribonucleotides triphosphate (dNTP) and DNA polymerase enzymes. The PCR stage consists of several stages: predenaturation, denaturation, elongating and post elongation. The time required is about 4 hours 31 minutes and there are 44 cycles.

PCR was performed using PCT-100 Programmable Thermal Controller with RAPD program. Thermocycler is a device capable of rapidly changing the different temperatures required in the PCR cycle (Louie et al., 2000: 475). In addition, another primer is used for PCR Mj Research machine with PCR time 04:31:36. In PCR used primer OPA 13 (5'-CAgCACCCAC-3') .In addition to the OPA primer 13, there were several primers used for the analysis of RAPD of salak plants, such as OPA 20 (Ediwirman, 2015). The results show that electrophoresis results after in PCR using detergent method and CTAB method was not much different. This was characterized by the number of bands and the appearance of DNA bands. The results showed the presence of DNA at $200 \mathrm{bp}$ to $1100 \mathrm{bp}$.

\section{CONCLUSION}

From the result of the research, it can be concluded that the result of DNA isolation (Salacca zalacca (Gaert.) Voss.) using CTAB method has better purity but using detergent method has higher DNA concentration. There is no difference in the quality of the detergent method and CTAB method. Further research about the modification of the detergent method is needed to obtain higher purity.

\section{ACKNOWLEDGEMENTS}

The authors gratefully acknowledge Balai Besar Bioteknologi dan Sumber Daya Genetik Pertanian (BBBiogen), Bogor, Indonesia for supported this study.

\section{REFERENCES}

Ardiana D W. 2009. Teknik Isolasi DNA genom tanaman pepaya dan jeruk dengan menggunakan modifikasi buffer CTAB. Buletin Teknik Pertanian. 14(1): 12-16.

Annisaurohmah, Herawati W, Widodo P. 2014. Biosfera 31(2): 71-83.

Ediwirman, Suliasyah I, Gustian and Jamsari. 2015. Specific RAPD fragments related with sex type in Salacca (Salacca edulis L.). IJAC.1(1): 34-46.

Faatih M. 2009. Isolasi dan digesti DNA kromosom. J Penelitian Sains Dan Teknologi. 20(1):61-67.

Fitriya RT, Ibrahim M, Lisdiana L. 2011. Keefektifan Metode Isolasi DNA Kit dan CTAB / NaCl yang Dimodifikasi pada Staphylococcus aureus dan Shigella dysentriae. Lentera Bio. 4(1): 87-92

Langga I F, Restu M, dan Kuswinanti T. 2012. Optimalisasi suhu dan lama inkubasi dalam ekstraksi DNA tanaman bitti (Vitex cofassus Reinw) serta analisis keragaman genetic dengan teknik RAPD- PCR, Jurnal Sains dan Teknologi 12: 265 276. 
Lim TK. 2012. Edible medicinal and non medicinal plant plants volume 1 fruits. Springer, London.

Louie M, Louie L, and Simor AE. 2000. The Role of DNA amplification of technology in the diagnosis of infectious diseases. Clin. Infect. Dis. 29: 475

Harsono T, Hartanta A. 2003. Biosistematika kultivar salak di bangkalan Madura. Floribunda 2(4): 95-101

Haryanto FF. 2010. Analisis kromosom dan stomata tanaman salak bali (Salacca zalacca var amboinensis ((Becc.) Mogea), salak padang sidempuan (Salacca sumatrana (Becc)). dan Salak Jawa (S. zalacca var zalacca (Becc) Mogea). [Undergraduate Thesis, Universitas Sebelas Maret, Surakarta. [Indonesian].

Milligan BG.1992. Plant DNA Isolation. In: A.R. Hoelzel. Molecular Genetic Analysis of Populations. A Practical Approach.Oxford University Press, New York

Mulyani Y, Purwanto A dan Nurruhwati I. 2011.Perbandingan beberapa metode Isolasi DNA untuk deteksi dini Koi Herpes Virus (KHV) pada ikan mas (Cyprinus carpio L.) Jurnal Akuatika.8:1-6.

Purnomo H. 2001. Budidaya Salak Pondoh. PT. Pabelan, Semarang,

Mogea JP. 1980. The flabellate- leaved species of Salacca (Palmae). REINWARDTIA. 9: 461-479.

Nasiri H, Forouzandeh M, Rasaee MJ, and Rahbarizadeh. 2005. Modofied salting- out method: high yield, high quality genomic DNA extraction from whole blood using laundry detergent.Journal of Clinical Laboratory Analysis 19: 229232.

Ni made G. 2005. Studies on Bali salak cultivars (Salacca zalacca var. amboinensis) (Aracaceae). Masters thesis, James Cook University, Australia.
Sambrook J. 1982.Fragment DNA in Bacterial System. Molecular Cloning A Laboratory manual. Cold Spring Harbor Laboratory, USA.

Semagn K, Bjornstad A, and Ndjiondjop MN. 2006. An overview of molecular marker methods for plants. African Journal of Biotechnology. 5(25): 2540-2568.

Suhandy, Diding, Yulia, Meinilwita, Kuncoro, Sapto, Rhinaldo, Wahyu, Kondo, Naoshi, Ogawa, Yuicihi.2010. The measurement of soluble solids concent in snake fruit (Salacca Edulis Reinw) cv. Pondoh using a portable spectrometer. IFAC Proceedings Volumes. 43:235-240.

Supriyadi, Suhardi, Suzuki M, Yoshida K, Muto T, Fujita A, Watanabe N. 2002. Changes in the volatile compounds and in the chemical and physical properties of snake fruit (Salacca edulis Reinw.) cv. Pondoh during maturation. J. Agric. Food. Chem. 50: 7627-7633.

Suskendriyati H, Wijayati A, Hidayah N, Cahyuningdari D. 2000. Studi Morfologi dan Hubungan Kekerabatan Varietas Salak Pondoh (Salacca zalacca (Gaert.) Voss.) di dataran tinggi sleman. Biodiversitas. 1(2): 59-64

Supapvanich S, Megia R, Ding P. 2011. Salak (Salacca zalacca (Gaertner) Voss). Woodhead Publishing Limited

Tenriulo, AE, Suryati, Parenrengi A, Rosmiat. Ekstraksi DNA rumput laut dengan metode fenol kloroform. Marina Chimica Acta 2:6-10.

Utami A, Meryalita R, Prihatin, NA, Ambarsari L, Kurniatin PA, Nurcholis W. 2012. Prosiding Seminar Nasional Kimia Unesa. Surabaya, $22^{\text {nd }}$ of February 2012. [Indonesian]. 